\title{
Kalendarium życia i dzialalności ks. Tomasza Kaczmarka
}

1950, 6 stycznia

1964-1968

1968, 14 września

1974, 15 czerwca

1974-1976

1976-1977

1977-1983

1984, styczeń

1984, kwiecień dzień urodzin w miejscowości Sobótka, pow. Koło (rodzice: Władysław i Kazimiera; rodzeństwo: bracia Stanisław i Andrzej).

nauka w Liceum Ogólnokształcącym w Kole, zakończona uzyskaniem matury.

początek formacji w Wyższym Seminarium Duchownym we Włocławku.

święcenia kapłańskie przyjęte z rąk ks. bp. Jana Zaręby. wikariat w Choczu n. Prosną. wikariat w Izbicy Kujawskiej.

studia w Rzymie w Instytucie Patrystycznym „Augustinianum" oraz uzupełniające w Papieskim Instytucie Archeologii; w 1981 uzyskany licencjat, a w 1983 doktorat z teologii i nauk patrystycznych (teza: „Sacramentum Christi” nell'insegnamneto di s. Cipriano).

kapelan biskupa ordynariusza, notariusz Kurii, wykładowca w WSD we Włocławku z zakresu Patrologii w kolejnych latach także zajęcia $\mathrm{z}$ jęz. łacińskiego i lektorat z jęz. włoskiego.

początek okresowych wyjazdów z konferencjami i wykładami do klasztoru Mniszek Kamedułek w Złoczewie; początek konferencji z zakresu doktryny Kościoła dla sióstr karmelitanek i sióstr „Wspólnej pracy” od Niepokalanej Maryi; począ- 
1984, listopad

1986, wrzesień

1987, grudzień

1989, lipiec

1989, sierpień

1990, wrzesień

1991, czerwiec

1991, październik

1992, 26 styczeń tek prac nad beatyfikacją Sługi Bożego bp. Michała Kozala pod kierunkiem o. Michała Machejka OCD, relatora Kongregacji Spraw Kanonizacyjnych.

formalne włączenie do grona cooperatores externi Kongregacji.

ukończenie w Kongregacji zbiorowego opracowania (wraz z o. M. Machejkiem i adw. Giulio Dante) Positio super martyrio dla sprawy bp. Kozala. funkcja kapelana u nowego ordynariusza diecezji, bp. Henryka Muszyńskiego; prowadzenie prac magisterskich jako promotor; w sumie ponad 100 do roku 2019 (WSD Włocławek, Studium Teologii we Włocławku, Wydział Teologiczny UMK Toruń). zakończenie funkcji kapelana biskupa ordynariusza i przejęcie funkcji dyrektora Instytutu Wyższej Kultury Religijnej we Włocławku.

początek wyjazdów misyjnych na tereny Związku Sowieckiego.

rozpoczęcie prac procesowych jako postulator sprawy beatyfikacji Sługi Bożego bp. Wojciecha Owczarka.

początek prac nad przygotowaniem procesu beatyfikacyjnego męczenników Kościoła w Polsce z czasu II wojny światowej.

nominacja na postulatora generalnego tegoż procesu. w bazylice katedralnej we Włocławku uroczysta sesja publiczna otwierająca proces; w kolejnych miesiącach następuje zorganizowanie trybunałów rogatoryjnych w 17 diecezjach; trwa kierowanie pracami zespołów procesowych w całym kraju; utworzenie Studium Teologii we Włocławku powiązanego 
1994, 26 stycznia

1994, maj

1995-1998

1999, 13 czerwca

2001, wrzesień

2001, październik

2003, październik

2004, 4 listopada

2008, 20 czerwca

2009, 19 grudnia

2009, 17 października współpracą naukową z Papieskim Wydziałem Teologicznym w Warszawie, Sekcji św. Jana Chrzciciela i kierowanie jego pracami do lipca 1994 roku. zakończenie na uroczystej sesji w bazylice katedralnej we Włocławku diecezjalnego etapu prac procesowych; miesiąc później materiały procesowe zostały przewiezione do Kongregacji. rozpoczęcie prac przy Kongregacji w charakterze postulatora przy Kongregacji oraz współpracownika zewnętrznego.

opracowanie Positio super martyrio dla sprawy 108 Męczenników.

udział w beatyfikacji męczenników w Warszawie. początek prac jako wykładowcy Wydziału Teologicznego UMK w Toruniu.

objęcie posługi diecezjalnego egzorcysty. nominacja ze strony ks. prymasa kard. Józefa Glempa na postulatora przy Kongregacji dla sprawy Stugi Bożego ks. Jerzego Popiełuszki i jednocześnie rozpoczęcie prac nad przygotowaniem Positio super martyrio. półroczna przerwa w zajęciach ze względu na stan zdrowia; rehabilitacja $\mathrm{w}$ instytutach kardiologicznych.

złożenie Positio do dyskusji teologicznej Kongregacji o męczeństwie za wiarę ks. Jerzego Popiełuszki; udział w dalszych pracach nad sprawą. zwieńczenie prac procesowych nad beatyfikacją ks. Jerzego Popiełuszki w postaci zatwierdzenia przez Benedykta XVI dekretu o męczeństwie za wiarę. nagroda drugiego stopnia rektora UMK w Toruniu „za osiągnięcia w dziedzinie naukowo-badawczej”. 
2010, 20 marca

2010, 18 maja

2010, 6 czerwca

2011, 28 czerwca

2016, 1 października

2017, październik-czerwiec

2017

2018 na prośbę biskupa ordynariusza Wiesława Meringa wyniesiony do godności prałata Jego Świątobliwości Benedykta XVI.

uzyskanie nagrody specjalnej „Civitas Christiana” w ramach 63. Nagrody im. Włodzimierza Pietrzaka. udział w beatyfikacji w Warszawie ks. Jerzego Popiełuszki w charakterze postulatora sprawy. uzyskanie tytułu doktora habilitowanego Nauk Teologicznych w zakresie Teologii Patrystycznej na Wydziale Teologicznym Uniwersytetu Opolskiego na podstawie całokształtu prac naukowych i rozprawy Eklezjalny wymiar męczeństwa w nauczaniu św. Augustyna; kontynuacja pracy naukowej na Wydziale Teologicznym UMK Torun i Studium Teologii we Włocławku oraz prac duszpasterskich.

przejście na emeryturę; zajęcia zlecone z patrologii na Wydziale Teologicznym dla alumnów WSD Włocławek.

zorganizowanie i przeprowadzenie procesu kanonizacyjnego w diecezji Creteil (Paryż) o cudzie przypisywanym wstawiennictwu bł. Jerzego Popiełuszki. kontynuacja prac nad przygotowaniem Positio super virtutibus dla sprawy beatyfikacji Sługi Bożego bpa. Wojciecha Owczarka

opracowanie materiału do dyskusji w Watykańskiej Kongregacji w procesie o cudzie z Creteil przypisywanemu bł. Jerzemu. 